\section{Re: En mann i 70-årene med infeksjon og alvorlig syre-base-forstyrrelse}

Det finnes studier som har vist en assosiasjon mellom laktacidose og tiaminmangel, både ved sepsis og ved enkelte andre tilstander $(1,2)$. Fant dere normalt nivå av tiamin hos denne pasienten?

\author{
Morten Juul Sundnes
}

morten.sundnes@me.com

Morten Juul Sundnes (f. 1973) er lege i spesialisering ved St. Olavs hospital. Ingen oppgitte interessekonflikter

\section{Litteratur \\ 1. Moskowitz A, Graver A, Giberson T et al. The relationship between lactate and thiamine levels in patients with diabetic ketoacidosis. J Crit Care 2014; 29: e5-8. 2. Andersen LW, Mackenhauer J, Roberts JC et al. Etiology and therapeutic approach to elevated lactate levels. Mayo Clin Proc 2013; 88: 1127-40.}

\section{E. Helskog og medarbeidere svarer:}

Her svarer forfatterne/forfatteren på et innlegg som er publisert på nett og $i$ Tidsskriftet nr. 9/2014.

Vi finner det underlig at Nina E. Jensen velger å se bort fra denne kasuistikkens ubestridelige faktum: at pasienten vi beskriver hadde en rekke psykotiske symptomer. Søkelyset på at elektrokonvulsiv terapi (ECT) kan ha en effekt på kronisk utmattelsessyndrom/myalgisk encefalopati (CFS/ME), og at dette betyr at pasienten led av $\mathrm{ME}$, er en grov diagnostisk forenkling. Det er dessuten ikke tilstrekkelig evidens for å bevise kausalitet, og heller ikke nok evidens til å konkludere med at elektrokonvulsiv terapi har effekt på pasienter med kronisk utmattelsessyndrom/myalgisk encefalopati.

Vi vil understreke at denne artikkelen ikke er noen anbefaling om å benytte elektrokonvulsiv terapi til pasienter med kronisk utmattelsessyndrom/myalgisk encefalopati. Det får gruppestudier med strenge vitenskapelige krav vurdere. Vår hensikt er å beskrive et pasientforløp hvor vi mener at pasienten ikke var tilstrekkelig utredet, spesielt med tanke på å utelukke psykiatriske diagnoser.

Jensen skriver at pasienter med kronisk utmattelsessyndrom/ myalgisk encefalopati kan oppleve lydhallusinasjoner, men vi lurer på om hun da mener hallusinasjoner med vrangforestillinger? Mange mennesker har hallusinasjoner av forskjellige modaliteter av ulike årsaker, uten at disse er realitetsbristende. Referansene som oppgis er også noe underlige, særlig artikkelen fra Young ME sufferers Trust. Denne artikkelen fremstår svært lite uavhengig, er ikke fagvurdert, er publisert av en interesseorganisasjon for barn og unge med kronisk utmattelsessyndrom/myalgisk encefalopati, og omhandler i all hovedsak barn, så vidt vi kan forstå. Det er vanskelig å se hvordan denne referansen, og referansen til en 13 år gammel bok, kan brukes for å legitimere at de beskrevne lydhallusinasjonene best lar seg forklare av kronisk utmattelsessyndrom/ myalgisk encefalopati. Ingen av disse referansene egner seg således til å trekke slutninger om diagnostisk validitet generelt.

Med mindre Jensen tar utgangspunkt i at kronisk utmattelsessyndrom/myalgisk encefalopati også er en psykoselidelse? Det kommer ikke klart frem, men vi tror ikke dette er hva Jensen forsøker å si.

At en diagnose består av kliniske observerbare symptomer, betyr ikke nødvendigvis at det er en enkel sak å gi pasienter riktig diagnose. I hvert fall ikke når symptomene er generelle og kan passe innunder mange forskjellige diagnoser. Jensen refererer til Canadian Consensus Criteria for CFS/ME $(1,2)$. Om man for eksempel tar for seg kriterium 4 om kognitive/nevrologiske kriterier, nevnes ti problemområder, deriblant konsentrasjonsproblemer. Dette er et symptom som er felles for så å si alle psykiatriske diagnoser. Det samme gjelder for mange av de andre kriteriene.

Som nevnt i vår artikkel, er det også verdt å merke seg at Helse- direktoratet ikke tar endelig stilling til hvilket av flere sett med diagnosekriterier som er i bruk, som bør være gjeldende (3).

Det er ingen tvil om at det må ryddes opp i utredning og behandling av kronisk utmattelsessyndrom/myalgisk encefalopati, og nok en gang kommer man ikke utenom at det må tas psykiatriske anamneser for å utelukke psykiske lidelser. Det er svært uheldig dersom pasienter som har en psykisk lidelse, blir behandlet som pasienter med kronisk utmattelsessyndrom/myalgisk encefalopati.

\section{Espen Helskog}

espenhauk@hotmail.com

Kristin Bjartveit

Espen Helskog (f. 1977) er psykolog ved Nedre Romerike DPS, Akershus universitetssykehus.

Ingen oppgitte interessekonflikter

Kristin Bjartveit (f. 1957) er spesialist i psykiatri og overlege ved Psykiatrisk avdeling Arendal, Sørlandet sykehus. Hun var tidligere ved Avdeling akuttpsykiatri, Akershus universitetssykehus.

Ingen oppgitte interessekonflikter.

\section{Litteratur \\ 1. Carruthers BM, Jain AK, De Meirleir KL et al. Myalgic encephalomyalitis/chronic fatigue syndrome: Clinical working definition, diagnostic and treatment proto- cols. J Chronic Fatigue Syndr 2003; 11: 7-115. \\ 2. Carruthers BM, van de Sande MI, De Meirleir KL et al. Myalgic encephalomyeli- tis: International Consensus Criteria. J Intern Med 2011; 270: 327-38. \\ 3. Helsedirektoratet. Nasjonal veileder. Pasienter med CFS/ME: Utredning, dia- gnostikk, behandling, rehabilitering, pleie og omsorg. Oslo: Helsedirektoratet, 2013. \\ Re: Medisinske funn i en tverrfaglig geriatrisk fallpoliklinikk}

Oslo universitetssykehus rapporterer om sine første erfaringer med en fallpoliklinikk (1) og finner ikke helt uventet at multimorbiditet og polyfarmasi er hyppig assosiert med falltendens. $13 \%$ av de henviste hadde hatt tidligere frakturer. Opprettelsen av fallpoliklinikken er et betimelig og velkomment tiltak.

Finske undersøkelser har vist at forekomsten av skader i forbindelse med fall er økende selv om den aldersspesifikke insidensen synes å være avtakende (2). Heldigvis fører fall også hos eldre oftest til relativt små skader, men om lag $7-8 \%$ av de fallulykkene som krever legetilsyn, fører til innleggelse i sykehus. Mer enn $70 \%$ av disse innleggelsene er foranlediget av frakturer (3). Interessant er det at insidenskurven for fall hos eldre er svært lik insidenskurven for hoftefrakturer. Frakturer er også en selvstendig risikofaktor både for nye fall og fremtidig redusert helse (3).

Uventet var det derfor at verken osteoporoseutredning eller frakturforebyggende behandling ble nevnt $\mathrm{i}$ artikkelen eller $\mathrm{i}$ den ledsagende lederen (4). En fallpoliklinikk må forventes å ha et vidt repertoar gitt både de mange årsakene til fall og de behandlingsmulighetene man har. Selv om ulike tiltak kan redusere falltilbøyeligheten hos en eldre person, viser flere undersøkelser at «fallerne» til tross for tiltakene vil fortsette å falle (5-7), om enn forhåpentligvis ikke så hyppig som tidligere. Man må derfor også vurdere hvilke andre skadeforebyggende tiltak som skal iverksettes. Frakturforebygging må her sies å være et sentralt element. Heldigvis finnes for dette formålet gode diagnostiske og behandlingsmessige tiltak (8) som jeg håper fallpoliklinikken vil ta med seg i sitt videre virke.

\section{Johan Halse}

johalse@online.no

Johan Halse (f. 1944) er daglig leder av Osteoporoseklinikken.

Oppgitte interessekonflikter: Forfatter har hatt konsulentoppdrag for MSD Norge AS og Lilly Norge AS. Han har mottatt honorar for foredrag og møtedeltakelse fra Amgen AB Norge. 
Litteratur

. Smebye KL, Granum S, Wyller TB et al. Medisinske funn i en tverrfaglig geriatrisk fallpoliklinikk. Tidsskr Nor Legeforen 2014: 134: 705-9.

2. Korhonen N Niemi S, Palvanen M et al. Declining age-adjusted incidence of fall-induced injuries among elderly Finns. Age Ageing 2012; 41: 75-9.

3. Stel VS, Smit JH, Pluijm SM et al. Consequences of falling in older men and women and risk factors for health service use and functional decline. Age Ageing 2004; 33: 58-65.

4. Roksund G. Falltendens hos eldre. Tidsskr Nor Legeforen 2014: 134: 688.

5. Gregg EW, Pereira MA, Caspersen CJPereira MACaspersen CJ. Physical activity, falls, and fractures among older adults: a review of the epidemiologic evidence. J Am Geriatr Soc 2000; 48: 883-93.

6. Gillespie LD, Robertson MC, Gillespie WJ et al. Interventions for preventing falls in older people living in the community. Cochrane Database Syst Rev 2012; 9: CD007146.

7. Palvanen M, Kannus P, Piirtola M et al. Effectiveness of the Chaos Falls Clinic in preventing falls and injuries of home-dwelling older adults: a randomised controlled trial. Injury 2014: 45: 265-71.

8. Kanis JA, McCloskey EV, Johansson $\mathrm{H}$ et al; Scientific Advisory Board of the European Society for Clinical and Economic Aspects of Osteoporosis and Osteoarthritis (ESCEO) and the Committee of Scientific Advisors of the International Osteoporosis Foundation (IOF). European guidance for the diagnosis and management of osteoporosis in postmenopausal women. Osteoporos Int 2013; 24: $23-57$.

\section{Mellingsæter svarer:}

Vi er enige med Johan Halse i at osteoporose er en svært viktig årsak til de sørgeligste resultatene av fall.

En vurdering av om det foreligger osteoporose og om det er aktuelt å henvise til bentetthetsmåling, hører med i en fallpoliklinikk. Vår erfaring er også at mange har en osteoporosediagnose fra tidligere, men uten at de får anbefalt behandling. Dette er en del av forklaringen på at så mange som $21 \%$ av pasientene fikk D-vitamin, eventuelt med kalsium, ved fallpoliklinikken, slik vi skriver i tabell 4 (1). Både kalsium/vitamin D, bisfosfonater og hoftebeskyttere er tiltak vi vurderer, men siden temaet for artikkelen var utredning av årsaker til fall, ble det ikke betont så sterkt.

\section{Marte Mellingsæter}

cmelling@online.no

Marte Mellingsæter (f. 1973) er lege ved geriatrisk avdeling, Oslo universitetssykehus

Ingen oppgitte interessekonflikter

\section{Litteratur}

1. Smebye KL, Granum S, Wyller TB et al. Medisinske funn i en tverrfaglig geriatrisk fallpoliklinikk. Tidsskr Nor Legeforen 2014; 134: 705-9.

\section{Re: PSA-måling og prostatakreft - overdiagnostisering og overbehandling?}

Breidablik og medarbeideres artikkel (1) er betimelig nå som professor Richard Albin, mannen som oppdaget PSA-testen, har skrevet bok og erklært at PSA ikke er en god indikator for cancer prostatae, og i mange tilfeller ikke burde vært brukt for dette formål (2). Debatten er ikke ny. I 1978 kjørte magasinet Der Spiegel en serie artikler om kreft med tittelen «Ingen angst for kreft» signert professor Julius Hackenthal (3). Her tas troverdigheten av kreftdiagnostikk opp, herunder bruken av mikroskop ved analyse av celler fra antatt prostatakreft. Konklusjonen er nedslående: Selv med elektron-mikroskopi var ikke diagnostikken av kreftceller hos dyr og mennesker entydig. Hva angår prostata var opptil $20 \%$ av protstakjertlene infiserte, og muligens var det da infeksjonsendringer man mistolket som kreft.

Debatten om korrekt diagnostikk er absolutt betimelig og er parallell til debatten om borreliose som verserer for tiden. I denne sammenheng har jeg som lege og forfatter drevet et toårig journalistisk arbeid som har resultert i en bok om flåttbårne sykdommer, der jeg har forsøkt å bringe klarhet i hvor troverdige diagnoser er
(4). Man har her en helt parallell situasjon til prostatakreft: Usikre serologiske tester og konflikter med mikroskopi. Som tidligere fysikkstudent ser jeg også parallellsituasjonen til fysikk: I teknologiens gråsone der våre identifaktorer for gjenkjennelse ikke lenger er entydige, inntrer Werner Heizenbergs usikkerhetsprinsipp, som sier at den som undersøker med sin metode vil påvirke det man undersøker så mye at entydighet i konklusjon om erkjennelse forsvinner. I atomfysikk lever man med dette. Kan vi leger leve med det? Og hva med pasientene? Og når situasjonen er usikker, er det vår angst for å skulle overse og ikke behandle kreft på et tidlig stadium som får oss til å «se» kreft der det ikke finnes med påfølgende feilbehandling? Er tiden moden for økt erkjennelsesteoretisk kunnskap og mer inngående selvransakelse (5)?

Bjørn Johan Øverbye

bjorn@dr-overbye.no

Bjørn Johan Øverbye (f 1947) er lege ved Arendal helsesenter AS Ingen oppgitte interessekonflikter

Litteratur

1. Breidablik HJ, Meland E, Aakre KM et al. PSA-måling og prostatakreft - overdiagnostisering og overbehandling? Tidsskr Nor Legeforen 2013; 133: 1711-6.

2. Albin RJ. The great prostate hoax: How big medicine hijacked PSA test and caused a public health disaster. NewYork: Palgrave MacMillian, 2014.

3. Hackenthal. Kein Angst für Krebs, Der Spiegel, 43/1978 s: 208-218.

4. Øverbye BJ. Flåttbårne sykdommer. Fevik: Veiviseren forlag, 2014

5. Dilts R, Hallbom T, Smith S. Beliefs. Portland: Metamorphous Press, 1990

\section{Re: Vitamin D - hvor mye er nok, og er mer bedre for helsen?}

Brustad \& Meyer (1) og Dahl \& Thorsby (2) gjør godt rede for sitt nøkterne syn på måling og vurdering av vitamin D-status. Vi er enige $i$ at en serumkonsentrasjon av 25-hydroksyvitamin D på $50 \mathrm{nmol}$ per liter sannsynligvis er tilstrekkelig for de fleste (1). Som forfatterne påpeker, er imidlertid dette kontroversielt. Vitamin D kan ha immunmodulerende effekter. Verdier av 25-hydroksyvitamin D mellom 75 og $125 \mathrm{nmol}$ per liter er forbundet med lav sykdomsrisiko og sykdomsaktivitet ved multippel sklerose (3), er bra for beinhelsa og er ikke toksiske. Inntil overbevisende resultater av randomiserte studier foreligger, vil vi anbefale dette serumnivået til personer med multippel sklerose.

Et viktig moment som ikke omtales, er at serumnivået av 25hydroksyvitamin D antagelig varierer betydelig gjennom året, $i$ hvert fall hos personer som ikke bruker tilskudd om vinteren. Repetert måling hos 88 personer med multippel sklerose gjennom to år viste at de laveste nivåene vanligvis ble nådd i mars/april, og var under halvparten av toppnivået i august/september (3). En person med «tilfredsstillende» nivå av 25-hydroksyvitamin D på $50 \mathrm{nmol}$ per liter i august, har sannsynligvis uttalt mangel på ettervinteren og våren. Disse målingene ble utført før interessen for vitamin D «tok av», hos personer som var instruert til ikke å bruke tran, og som var lite preget av sykdommen. De er derfor sannsynligvis nokså representative for store deler av befolkningen som ikke bruker store doser vitamin D-tilskudd. På grunnlag av disse dataene laget vi en "vitamin D-kalkulator", der man ved å plotte inn ett enkelt nivå og måletidspunkt, får estimert personens vitamin Dstatus gjennom året (4). Kalkulatoren er tilgjengelig på hjemmesiden til Akershus universitetssykehus (5).

Hvordan bør klinikere forholde seg? Personer med en alminnelig sunn livsstil og som spiser fisk regelmessig eller bruker vitamin Dtilskudd /tran, trenger ikke å måle sitt 25-hydroksyvitamin D-nivå. Dersom man først måler 25-hydroksyvitamin D, for eksempel hos personer med kronisk sykdom og risiko for mangel, må måletidspunktet tas i betraktning. Følgende tommelfingerregel kan brukes: 